Hugoye: Journal of Syriac Studies, Vol. 13.2, 121-124

(C) 2010 by Beth Mardutho: The Syriac Institute and Gorgias Press

\title{
INTRODUCTION TO HUGOYE 13.2: PHILOXENOS OF MABBUG ONE MORE TIME
}

\author{
ROBERT A. KITCHEN \\ KNOX-METROPOLITAN UNITED CHURCH \\ REGINA, SASKATCHEWAN
}

While Philoxenos, bishop of Mabbug, may not enjoy the same reputation as more prolific authors in the Syriac language-e.g., Ephrem, Jacob of Serug, or Bar Hebraeus are better known-he was not an underachiever. The Discourses at 625 pages of Syriac text is one of the longest sustained arguments in Syriac literature, and his many letters and commentaries add up to a considerable corpus. This is one of the reasons why we are presenting a second issue of Hugoye volume 13 focusing on Philoxenos-he wrote too much for us to be satisfied with a brief overview.

The first ever conference to examine the works of Philoxenos of Mabbug was conducted on May 3, 2008, "Reconsidering Philoxenos of Mabbug," at the Center of Theological Inquiry, Princeton, New Jersey. Organized by David Michelson and Robert Kitchen, the symposium was sponsored by Center of Theological Inquiry, Gorgias Press, and Princeton University (including the following units: Center for the Study of Religion, Group for the Study of Late Antiquity, and the Program in Hellenic Studies). Five speakers from five countries provided the program (further details are in the symposium report in Hugoye 13.1) which acquired the euphemistic title, "Philoxenos Fest." Our first issue presented articles by Daniel King, Fr. Roger-Youssef Akhrass, and Robert Kitchen, as well as an extended review of the revised translation of Philoxenos' Discourses in the French patristic series, Sources 
Chrétiennes. There was significant response to the renewed study of Philoxenos and now four more articles are being brought forward, as well as a bibliographical clavis.

Adam C. McCollum, settling in as Lead Cataloguer, Eastern Christian Manuscript Project, at the Hill Museum \& Manuscript Library, St. John's University, Collegeville, Minnesota, offers an article on an Arabic scholion on Genesis 9:18-21 attributed to Philoxenos of Mabbug. There are a number of texts attributed to Philoxenos in Arabic and Ethiopic literature, but few that appear to be authentic. This particular scholion, featuring midrashic details regarding Noah's drunkenness, probably owes its Syriac origins to Ephrem. McCollum sorts out the sources from Jewish provenance, but gives full attention to the passage in Ephrem's Commentary on Genesis and in several hymns that treat this Biblical passage.

Dana Iuliana Viezure, Assistant Professor, Religious Studies Department, Seton Hall University, and one of the Phest lecturers, examines the shift in literary strategies utilized by Philoxenos in his letter-writing over the course of his ecclesiastical career. Viezure identifies four periods of letters extending over nearly forty years. The shift in emphases moves at first from scriptural reasoning in his doctrinal argumentation, with judicious use of paradox à la Ephrem, to a more strident emphasis on the personal background of the heretics rather than the heresies, to finally a more gracious attitude towards opponents developed through contact with the issues and strategies of Greek Miaphysite thought—but then the absence of Ephrem from his references is striking.

J. Edward Walters, a doctoral student at Princeton Theological Seminary, presents a summary of his masters thesis under Jeff Childers at Abilene Christian University on the so-called Philoxenian translation of the New Testament. The co-editors wish to thank Dr. Andreas Jückel for his kind assistance in this project.

The basic problem is that the Philoxenian version has not survived, except perhaps in the works of Philoxenos. Walters begins the journey by focusing on the exegetical and theological writings of the bishop and comparing his citations of several selected Gospel passages with the Peshitta and the later Harclean version that was reputed to have built upon the work of the Philoxenian. Walters demonstrates the nuances with which the Philoxenian version addressed perceived doctrinal and philological deficiencies in the Peshitta. 
David M. Odorisio, a member of the International Thomas Merton Society and a 2008 recipient of its Shannon Fellowship Award, has provided a very different direction in the modern reception of Philoxenos. He has transcribed several lectures of Thomas Merton, O.C.S.O., given while the novice master at Our Lady of Gethsemane Abbey, on The Discourses of Philoxenos and their implication for the spiritual life of Trappist monks in the 1960's. These audio-recorded lectures from the Thomas Merton Center archives, Bellarmine University, Louisville, Kentucky, are transcribed and published here by David Odorisio for the first time. Merton did not have any knowledge of Syriac language and literature, but discovered Philoxenos in Eugène Lemoine's translation and introduction in the French Sources Chrétiennes series (vol. 44, Paris: 1956) (cf. my review article in Hugoye 13.1, "Philoxène de Mabboug. Homélies. Introduction, traduction et notes par Eugène Lemoine"). While Syriacists may take issue with Merton's interpretation at points, one cannot help be caught up in his excitement for and insight into Philoxenos' monastic spirituality.

David A. Michelson, Assistant Professor of History, University of Alabama and co-editor of these two special issues of Hugoye 13, offers a bibliographical clavis of the texts and studies of Philoxenos, a critical tool for future research on an author whose significant corpus is widely dispersed and not amply studied.

Obviously, the efforts of these two issues barely scratch the surface of Philoxenos, his life, his writings, and his theological reflections, but hopefully a few new perspectives have been explored as well as perennial issues looked at in a new light. By the diversity of these articles, it is apparent how broad the scope of Philoxenos' works entails.

As for suggestions of further work on the Bishop of Mabbug, one would simply be to ask for more studies that focus upon particular texts, their settings, use of language and the Bible, and his various forays into the doctrinal issues of the day. Much of the research heretofore has viewed Philoxenos and his writings and life as a totality, but seldom stops to narrow in on the occasion and content of a single text. To switch around the metaphor, a sharper examination of the trees may help us to understand the forest more clearly and accurately. 
Neither last nor least, the suggestion of Andrea Sterk, University of Florida and Center of Theological Inquiry, and one of the moderators of the Princeton Phest, may nudge us towards solving one piece of the Philoxenian puzzle. How did Philoxenos go about being a bishop? What episcopal and pastoral duties did he undertake that were in keeping with the patterns of contemporary bishops and which ones were idiosyncratic?

May these two issues of Hugoye 13 devoted to Philoxenos of Mabbug inspire, encourage, and agitate more readers to a deeper examination of this major theologian, ecclesiastical controversialist, and elegant writer of the Syriac language. 